Research Paper

\title{
Legal Protection for Children Victims of Narcotics Abuse in Riau Province
}

\section{Yusuf Daeng ${ }^{1}$, Muhammad Fadly Daeng Yusuf ${ }^{1}$}

${ }^{1}$ Faculty of Law, Universitas Lancang Kuning. Riau, Indonesia.

Article History

Received:

16.08.2021

Revised:

14.09.2021

Accepted:

22.09.2021

*Corresponding Author:

M. Yusuf Daeng

Email:

m.yusufdaeng@unilak.ac.id

This is an open access article, licensed under: $C C-B Y-S A$

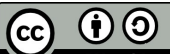

Abstract: Narcotics abuse can be categorized as a criminal act as regulated in Law Number 35 of 2009 concerning Narcotics. The method used in this research is socio-legal research. In Law Number 35 of 2009 concerning Narcotics, there is no distinction between the abuse committed by children who are already drug addicts and children who are victims of narcotics abuse and are taking narcotics for the first time, so that these children are combined at the time of the crime. It is hoped that there will be political will from the Government of the Republic of Indonesia to revise Law Number 35 of 2009 concerning Narcotics in order to provide legal protection for children who are victims of narcotics abuse. One of the obstacles faced by the Riau Regional Police in eradicating narcotics abuse by children is the minimal role of parents who are willing to report their children. Therefore, the Riau Regional Police should cooperate with religious leaders from MUI, traditional leaders from LAM Riau, as well as community leaders in order to provide enlightenment to the public about the dangers of narcotics abuse for the future of children.

Keywords: Abuse, Legal Protection, Narcotics. 


\section{Introduction}

In order to realize a prosperous, just and prosperous Indonesian society that is materially and spiritually evenly distributed based on Pancasila and the 1945 Constitution of the Republic of Indonesia, the quality of Indonesian human resources as one of the national development capital needs to be maintained and their health status improved. In order to improve the health status of Indonesian human resources in the context of realizing the welfare of the people, it is necessary to make efforts to improve in the field of treatment and health services, among others by seeking the availability of certain types of narcotics that are urgently needed as drugs on the one hand, as well as preventing and eradicating the dangers of abuse and narcotics trafficking on the other side [1].

One of the causes that can damage health is drug abuse [2]. Narcotics are actually substances or drugs that are very useful and necessary for the treatment of certain diseases. However, if misused or used not in accordance with standard treatment, narcotics can have very detrimental effects on individuals and society, especially children. This will be more detrimental if accompanied by abuse and illicit trafficking of narcotics which can result in greater danger to the life and cultural values of the nation, which in the end will be able to destroy a human civilization [3].

According to Article 1 number 1 of Law Number 35 of 2009 concerning Narcotics, it is explained that narcotics are substances or drugs derived from plants or non-plants, both synthetic and semisynthetic, which can cause a decrease or change in consciousness, loss of taste, reduce to eliminate pain, and can lead to dependence.

Narcotics abuse can be categorized as a criminal act as regulated in Law Number 35 of 2009 concerning Narcotics. The crime of narcotics abuse has been transnational in nature, carried out using a high modus operandi, advanced technology, supported by an extensive network of organizations, and has caused many victims, especially among children who are very dangerous to the lives of the community, nation and state [4].

Riau Province is one of the main entry points for narcotics trafficking from abroad to Indonesia. The crime of narcotics abuse in Riau Province has disturbed the public because it is not only committed by adults, but also by children, who should be prepared as the future generation of the nation and state. There are many factors that can cause a child to be involved in a criminal case of drug abuse, one of which is from promiscuity from the surrounding environment.

To prevent and eradicate criminal acts of narcotics abuse, especially those committed by children, Law Number 35 of 2009 concerning Narcotics regulates the expansion of wiretapping investigation techniques, covert purchasing techniques, and supervised delivery techniques to track and uncover narcotics trafficking. In addition, considering the unstable character of children, a familial approach must be taken so that the child is willing to work together to help uncover the perpetrators of narcotics traffickers. Based on data obtained from the Riau Regional Police, it is known that in 2019 there were 41 cases of narcotics abuse crimes committed by children in Riau Province. However, in Law Number 35 of 2009 concerning Narcotics, there is no distinction regarding the abuse committed by children who have become narcotics addicts with children who are victims of narcotics abuse and are taking narcotics for the first time, so that these children are combined at the time of detention.

From the background of the problems described above, how is the legal protection for children victims of narcotics abuse in Riau Province?

\section{Research Methodology}

Legal research is a scientific activity that is based on certain methods, systematics, and thoughts that aim to study one or several specific legal phenomena by analyzing them [5]. The method used in this research is socio-legal research. Socio-legal research is a research conducted by explaining the implementation of laws and regulations on problems in society [6]. Source of data used in this research are primary data and secondary data. Primary data is data obtained directly from observations and interviews at the research location; while secondary data is data obtained from scientific journals, legal literature, and statutory regulations. Respondents in this research were Riau Regional Police. Data collection techniques used in this research were observation, interviews, and literature study. The data analysis technique used in this study is qualitative analysis.

\section{Discussions}

Law Number 35 of 2009 concerning Narcotics is the legal basis that regulates criminal acts of narcotics abuse. Narcotics are substances or drugs derived from plants or non-plants, both synthetic 
and semi-synthetic, which can cause a decrease or change in consciousness, loss of taste, reduce to eliminate pain, and can cause dependence [7]. Narcotics are regulated in Law Number 35 of 2009 concerning Narcotics based on justice, protection, humanity, order, protection, security, scientific values, and legal certainty. Law Number 35 of 2009 concerning Narcotics aims to:

1. Ensure the availability of narcotics for the benefit of health services and/or the development of science and technology.

2. Prevent, protect and save the Indonesian people from narcotics abuse.

3. Eradicating illicit trafficking of narcotics and narcotic precursors.

4. Guarantee the arrangement of medical and social rehabilitation efforts for narcotics abusers and addicts.

Narcotics abuse can be categorized as a criminal act as regulated in Law Number 35 of 2009 concerning Narcotics. The crime of narcotics abuse is an extraordinary crime, apart from its broad impact, it is also because the crime of narcotics abuse is not only committed by adults, but also by children. Therefore, children as the future generation of the nation must be protected from the dangers of narcotics. Child protection is all activities to guarantee and protect children and their rights so that they can live, grow, develop, and participate optimally in accordance with human dignity and protection from violence and discrimination. Child protection in Indonesia as regulated in Law Number 23 of 2002 concerning Child Protection aims to ensure the fulfillment of children's rights so that they can live, grow, develop, and participate optimally in accordance with human dignity and protection, and receive protection from violence, and discrimination for the realization of quality, noble, and prosperous Indonesian children.

The rights of children are regulated in Law Number 23 of 2002 concerning Child Protection which was later amended by the enactment of Law Number 35 of 2014 concerning Amendments to Law Number 23 of 2002 concerning Child Protection, namely as follows [8]:

1. Every child has the right to be able to live, grow, develop, and participate fairly in accordance with human dignity and rights, as well as to receive protection from violence and discrimination.

2. Every child has the right to a name as self-identity and citizenship status.

3. Every child has the right to worship according to his religion, think, and express according to his level of intelligence and age under the guidance of his parents or guardians.

4. Every child has the right to know his parents, to be raised, and to be cared for by his own parents. In the event that for some reason the parents cannot guarantee the growth and development of the child or the child is neglected, then the child has the right to be cared for or appointed as a foster child or adopted child by another person in accordance with the provisions of the applicable laws and regulations.

5. Every child has the right to obtain health services and social security in accordance with their physical, mental, spiritual and social needs.

6. Every child has the right to receive education and teaching in the context of personal development and intelligence level in accordance with interests and talents.

7. Every child is entitled to protection in the education unit from sexual crimes and violence committed by educators, education staff, fellow students, and/or other parties.

8. In addition to the children's rights as referred to above, children with disabilities have the right to special education and children who have advantages have the right to special education.

9. Every child has the right to express and have his opinion heard, receive, seek, and provide information according to his level of intelligence and age for the sake of his development in accordance with the values of decency and propriety.

10. Every child has the right to rest and take advantage of free time, hang out with children of the same age, play, have recreation, and be creative according to their interests, talents, and intelligence levels for self-development.

11. Every child with a disability has the right to receive rehabilitation, social assistance, and maintenance of the level of social welfare.

12. Every child while in the care of parents, guardians, or any other party responsible for the care has the right to receive protection from treatment:

a. Discrimination. 
b. Exploitation, both economic and sexual.

c. Neglect.

d. Cruelty, violence, and persecution.

e. Injustice.

f. Other mistreatment.

13. Every child has the right to be cared for by his own parents, unless there are valid reasons and/or legal rules indicating that the separation is in the best interests of the child and is a final consideration.

14. In the event of a separation as referred to above, the child still has the right to:

a. Meet face-to-face and have regular personal contact with his parents.

b. Receive care, maintenance, education, and protection for the process of growth and development from both parents according to their abilities, talents, and interests.

c. Obtain financing for living from their parents.

d. Other children's rights.

15. Every child has the right to obtain protection from abuse in political activities, involvement in armed conflicts, involvement in social unrest, involvement in events that contain elements of violence, involvement in war, and sexual crimes.

16. Every child has the right to obtain protection from targets of abuse, torture, or inhumane punishment.

17. Every child has the right to freedom in accordance with the law.

18. Arrest, detention or imprisonment of a child is only carried out if it is in accordance with applicable law and can only be done as a last resort.

19. Every child who is deprived of his liberty has the right to:

a. receive humane treatment and their placement is separated from adults.

b. obtain legal aid or other assistance effectively in every stage of the applicable legal remedies.

c. defend themselves and obtain justice before an objective and impartial juvenile court in a trial closed to the public.

20. Every child who is a victim or perpetrator of sexual violence or who is in conflict with the law has the right to confidentiality.

21. Every child who is a victim or perpetrator of a criminal act is entitled to legal aid and other assistance.

The state, government and local government are obliged and responsible for respecting the fulfillment of children's rights without distinction of ethnicity, religion, race, class, gender, ethnicity, culture and language, legal status, birth order, and physical and/or mental condition. Narcotics are substances or drugs that are very useful and necessary for the treatment of certain diseases. However, if it is misused or used not in accordance with medical standards, it can have very detrimental consequences for individuals or society, especially children. This will be more detrimental if accompanied by abuse and illicit trafficking of narcotics which can result in greater danger to the life and cultural values of the nation, which in the end will be able to weaken national security.

In order to prevent and eradicate the abuse and illicit trafficking of narcotics which is very detrimental and endangers the lives of the community, nation and state, the General Assembly of the People's Consultative Assembly in 2002 through the Decree of the People's Consultative Assembly Number VI/MPR/2002 has recommended to the House of Representatives and the President of the Republic of Indonesia. Indonesia to make changes to Law Number 22 of 1997 concerning Narcotics [9]. Law Number 22 of 1997 concerning Narcotics regulates efforts to eradicate narcotics crimes through threats of fines, imprisonment, life imprisonment, and death sentences. In addition, Law No. 22/1997 on Narcotics also regulates the use of narcotics for medical and health purposes and regulates medical and social rehabilitation. However, in reality narcotics crime in society shows an increasing trend, both quantitatively and qualitatively, with widespread victims, especially among children.

Narcotics crimes are no longer carried out individually, but involve many people who are together, even an organized syndicate with a wide network that works neatly and very secretly, both at the national and international levels. Based on this, in order to increase efforts to prevent and eradicate narcotics crimes, it is necessary to update Law No. 22 of 1997 concerning Narcotics. This is also to prevent an increasing trend, both quantitatively and qualitatively, with widespread victims, especially 
among children, youth, and the younger generation in general. Therefore, on October 12, 2009 Law No. 35 of 2009 on Narcotics was passed.

In order to protect children from the dangers of narcotics abuse and prevent and eradicate illicit narcotics trafficking, Law Number 35 of 2009 concerning Narcotics also regulates narcotics precursors because narcotic precursors are substances or starting materials or chemicals that can be used in the manufacture of narcotics. . In Law Number 35 of 2009 concerning Narcotics, it is attached about narcotic precursors by classifying the types of narcotic precursors. In addition, it also regulates criminal sanctions for abuse of narcotic precursors for the manufacture of narcotics. To create a deterrent effect on perpetrators of abuse and illicit trafficking of narcotics and narcotics precursors, it is regulated regarding the weighting of criminal sanctions, both in the form of a special minimum sentence, imprisonment of 20 (twenty) years, life imprisonment, and death penalty. The criminal weighting is carried out based on the class, type, size, and amount of narcotics [10].

To more effectively prevent and eradicate abuse and illicit trafficking of narcotics and narcotics precursors, it is regulated regarding the strengthening of existing institutions, namely the National Narcotics Agency which is regulated in Presidential Regulation Number 83 of 2007 concerning the National Narcotics Agency, Provincial Narcotics Agency, and District Narcotics Agency. City. The National Narcotics Agency is a non-structural institution located under and directly responsible to the President of the Republic of Indonesia, which only has the task and function of coordinating. In Law Number 35 of 2009 concerning Narcotics, the National Narcotics Agency was upgraded to a nonministerial government institution and strengthened its authority to conduct investigations and investigations. The National Narcotics Agency is located under the President of the Republic of Indonesia and is responsible to the President of the Republic of Indonesia. In addition, the National Narcotics Agency also has representatives in the provinces and districts/cities as vertical agencies, namely the provincial National Narcotics Agency and the district/city National Narcotics Agency.

To further strengthen institutions, it is also regulated regarding all assets or property resulting from narcotics crimes and narcotics precursors and money laundering crimes from narcotics and narcotics precursors based on court decisions that have obtained legal force and are still confiscated for the state and used for the interest of implementing prevention and eradication of abuse of illicit trafficking of narcotics and narcotics precursors as well as medical and social rehabilitation efforts, especially for children.

Law Number 35 of 2009 concerning Narcotics also regulates the participation of the community in efforts to prevent and eradicate abuse of narcotics and narcotics precursors, including the awarding of awards for community members who have contributed to the prevention and eradication of abuse of narcotics and narcotics precursors. The award is given to law enforcers and the public who have contributed to the prevention and eradication of abuse and illicit trafficking of narcotics and narcotics precursors.

However, in Law Number 35 of 2009 concerning Narcotics, there is no distinction regarding the abuse committed by children who have become narcotics addicts with children who are victims of narcotics abuse and are taking narcotics for the first time, so that these children are combined in his detention. For this reason, it is hoped that there will be political will from the Government of the Republic of Indonesia to revise Law Number 35 of 2009 concerning Narcotics.

Riau Province is one of the main entry points for narcotics trafficking from abroad to Indonesia. The crime of narcotics abuse in Riau Province has disturbed the public because it is not only committed by adults, but also by children, who should be prepared as the future generation of the nation and state. There are many factors that can cause a child to be involved in a criminal case of narcotics abuse, one of which is promiscuity from the surrounding environment.

The crime of narcotics abuse in Riau Province is already in an alarming phase because narcotics abuse is not only carried out by adults, but also by children, both children who are still in school and who have dropped out of school, become narcotics users. One of the obstacles faced by the Riau Regional Police in eradicating criminal acts of narcotics abuse committed by children is the minimal role of parents who are willing to report family members who are drug users for fear of their children being arrested and imprisoned.

The decline in public trust in the police institution is due to the low values of justice in law enforcement. There is a sentence that is believed by the public that the law is sharp down but blunt up. There are a lot of drug traffickers who should have received severe punishments, but have been given light sentences, even only being rehabilitated. This can happen due to the influence of wealth owned 
by the drug dealers. Of course this is very contrary to one of the characteristics of the rule of law, namely a judiciary that is free from the influence of any other power or force and is impartial [11].

Based on Article 128 of Law Number 35 of 2009 concerning Narcotics, it is emphasized that parents or guardians of minors who become narcotics addicts who intentionally do not report it to the government, are sentenced to a maximum imprisonment of 6 months or a maximum fine of $\mathrm{Rp}$. $1,000,000.00$. Therefore, parents are expected to be willing to cooperate by reporting their children who are drug users because their children will not be prosecuted. Based on Law Number 35 of 2009 concerning Narcotics, it is regulated that children who are not old enough to become narcotics addicts and have been reported by their parents or guardians are not criminally prosecuted. However, most people do not know about the law, especially Law Number 35 of 2009 concerning Narcotics [12], so they don't want to report their child for fear that their child will be caught by the police and imprisoned.

The Riau Regional Police should cooperate with religious leaders such as MUI leaders, traditional leaders such as LAM Riau figures, as well as community leaders in order to provide counseling as well as enlightenment to the community about the dangers of narcotics abuse for life, especially for children who should be prepared as the next young generation the future of the nation and state.

In Pekanbaru City, legal protection for children in narcotics abuse cases has not been implemented because there are still children who are convicted of narcotics abuse [13]. Soerjono Soekanto suggests that there are five factors that influence law enforcement, namely the law itself, law enforcement factors, facilities that support law enforcement, community factors, and cultural factors [14]. In order to eradicate the crime of narcotics abuse in Riau Province which is already very worrying, it is necessary to have strict law enforcement accompanied by the application of sanctions that can provide a deterrent effect, namely the application of the death penalty to perpetrators of narcotics abuse [15].

\section{Conclusions}

Narcotics abuse can be categorized as a criminal act as regulated in Law Number 35 of 2009 concerning Narcotics. In Law Number 35 of 2009 concerning Narcotics, there is no distinction between the abuse committed by children who are already drug addicts and children who are victims of narcotics abuse and are taking narcotics for the first time, so that these children are combined at the time of the crime. Detention. It is hoped that there will be political will from the Government of the Republic of Indonesia to revise Law Number 35 of 2009 concerning Narcotics in order to provide legal protection for children who are victims of narcotics abuse. One of the obstacles faced by the Riau Regional Police in eradicating narcotics abuse by children is the minimal role of parents who are willing to report their children. Therefore, the Riau Regional Police should cooperate with religious leaders such as MUI leaders, traditional leaders such as Riau LAM figures, and community leaders in order to provide enlightenment to the public about the dangers of narcotics abuse for the future of children.

\section{References}

[1] G. Supramono, Indonesian Drug Law. Yogyakarta: Djambatan, 2004.

[2] A. Iskandar, Narcotics Law Enforcement. Jakarta: Elex Media Komputindo, 2015.

[3] S. Partodiharjo, Get to know drugs and fight their abuse. Jakarta: Esensi, 2006.

[4] A. Sofyan, Drugs Targeting Your Child: a Guide to Overcoming the Dangers of Drugs among Adolescents. Jakarta: Prestasi Pustaka Publisher, 2007.

[5] S. Soekanto, Introduction to Legal Research. Jakarta: UI Press, 2007.

[6] Z. Ali, Legal Research Methods. Jakarta: Sinar Grafika, 2013.

[7] H. Sasangka, Narcotics and Psychotropics in Criminal Law. Bandung: Mandar Maju, 2019.

[8] R. Saraswati, Child Protection Law in Indonesia. Bandung: Citra Aditya Bakti, 2015.

[9] M. Daud, Legal Politics in Indonesia. Jakarta: LP3ES, 1998.

[10] Z. O. Jainah, Legal Culture of Law Enforcement in the Eradication of Narcotics Crime. Jakarta: Rajawali Pers, 2019.

[11] A. S. Utama, "Public Trust in Law Enforcement in Indonesia," Ensiklopedia Social Review Journal, vol. 1, no. 3, 2019.

[12] B. Harefa, and V. Ariyanti, Regarding the Development of the Juvenile Criminal Justice System and Narcotics Crime in Indonesia. Yogyakarta: Deepublish, 2010. 
M. Yusuf Daeng, Muhammad Fadly Daeng Yusuf.

Legal Protection for Children Victims of Narcotics Abuse in Riau Province.

International Journal of Law and Public Policy, vol. 3, no. 2, pp. 100-106, September 2021. DOI: 10.36079/lamintang.ijlapp-0302.265

[13] Fahmi, R. Iqsandri, and Rizana. "Legal Protection of Children from Narcotics Abuse in Pekanbaru City Based on Law Number 35 of 2009 concerning Narcotics," Journal of Gagasan Hukum, vol. 3, no. 1, 2021.

[14] S. Soekanto, Factors Affecting Law Enforcement. Jakarta: Rajawali Pers, 2013.

[15] R. Iqsandri, "Law Enforcement against Criminal Acts of Narcotics Abuse in Riau Province Based on Law Number 35 Year 2009 concerning Narcotics," Ensiklopedia Social Review Journal, vol. 1, no. 3, 2019. 